\title{
Biomarker assessment of lanthanum on a freshwater invertebrate, Dreissena polymorpha
}

\author{
Houda Hanana*, Patrice Turcotte, Martin Pilote, Joëlle Auclair, Christian Gagnon and François \\ Gagné* \\ *Aquatic Contaminant Research Division, Environment and Climate Change Canada, 105 McGill, Montreal, Quebec, \\ Canada $\mathrm{H} 2 \mathrm{Y} 2 \mathrm{E} 7$
}

Received: 18 January, 2017; Accepted: 25 January, 2017; Published: 06 February, 2017

*Corresponding author: Houda Hanana, Aquatic Contaminant Research Division, Environment and Climate Change Canada, 105 McGill, Montreal, Quebec, Canada, Tel: 514496 4384; Fax: 514496 7398; E-mail: houda.hanana@yahoo.fr

François Gagné, Aquatic Contaminant Research Division, Environment and Climate Change Canada, 105 McGill, Montreal, Quebec, Canada, Tel: 514496 7105; Fax: 514496 7398; E-mail: francois.gagne@canada.ca

\begin{abstract}
The toxicological understanding of rare earth elements (REEs) in the aquatic environment is very limited and concerns are rising about their safety to the environment. This study aimed to determine the bioavailability of Lanthanum (La) in zebra mussel, to evaluate its effects after 14 and 28 days through a multi biomarker approach and to estimate the cumulative effects of exposure to this lanthanide and air-time survival. Results showed that La was bioaccumulated in mussels but did not trigger metallothionein induction. In addition, La caused an antioxidant and prooxidant effects depending on the concentration and the duration of exposure but no genotoxicity was found. A significant decrease in glutathione-S-transferase activity was observed after 14 days but not after 28 days of exposure. Results revealed that low concentration of La enhanced citrate synthase activity, while high concentration trend to decrease its activity. Furthermore, this lanthanide did not significantly affect the airtime survival and mussel weight by comparison to control mussels. We suggested that La could contribute in the resistance of mussels to stress induced by air exposure by improving TCA cycle. This study demonstrates that La has diverse effect on mussel but further experiments are needed to elucidate its exact mechanism of action.
\end{abstract}

Keywords: Rare earth elements, lanthanum, Zebra mussels, Bioavailability, Oxidative stress, Genotoxicity.

\section{Introduction}

Rare earth elements (REEs) are a group of 17 elements including the lanthanide groups and two other elements, scandium and yttrium, closely related to lanthanides. REEs are naturally present in the environment and they have an essential role in the efficient function of the world's economy [1]. Their unique physical and chemical properties make them indispensable for a wide variety of applications in industrial, agricultural and medical sectors [2]. The global production of REEs has increased since 1980/1990 (EPA, 2012) due to their increased use in industry which was estimated about 84,000 tons of oxides in 2003 [3]. However, this growing use of REEs is accompanied by enrichment to the environment [4]. Indeed, REE senter the groundwater and eventually migrate into rivers and lakes [5] and reach humans through trophic transfer [6, 7]. Despite their widespread applications, environmental risks related to REEs have received little attention which explains the paucity of data about their bioavailability and ecotoxicological impact. Thus, more research on the environmental impacts and biological effects of REE sis required [8].

Lanthanum (La), a representative element of light REEs, is widely used in electronics and optoelectronics, lighters, ceramics, battery [9] and also to stimulate the growth of agricultural products [10]. Therefore, this element is considered of specific interest as one of the major lanthanides found in industrial effluents [11]. Although dissolved lanthanum species (La3+) represent a very small proportion of lanthanum compounds in water and sediment, they are bioavailable and cause adverse effects in living biological systems [12]. In fishes and amphibians, several effects of La have been reported particularly on nervous systems [13,14], excretory organs [15] and smooth muscles [1618]. Previous study demonstrated also that La3+ delayed zebra fish embryo and larval development, decreased survival and hatching rates and causes tail malformation in a concentration -dependent way [19]. Studies performed with crustaceans are focused mainly in evaluating the effect of La on survival, growth and reproduction $[20,21,22]$ and showed the highest sensitivity of those organisms towards La-ions dissolved from $\mathrm{LaCl}_{3}$. In our Knowledge, few reports on La effects in marine bivalves have been published before now [23, 24, 25]. Given the lack of data for aquatic organisms, studies with mammals are provided. The trivalent La3+interfere with the immune defense and the function of the liver, spleen, heart and blood vessels and brain [26]. Previous studies indicated that lanthanum chloride accumulated in brain [10] alter the learning capacity and memory in animals 
$[10,27,28]$. Researchers have also shown that La3+entered hepatocytes [29] accumulated and induced oxidative damage in mitochondria [30]. In fish liver, this element induced an inhibitory action on mitochondrial energy turnover [31]. The injury caused by La3+ may be attributed to the occurrence of oxidative stress and to the homeostatic disturbances of essential elements and enzymes [10]. Indeed, the mode of action of La3+on tissues and cells is similar to other lanthanides. In vitro, it reacts with various tissue components, like nucleoproteins, amino acids, phospholipids, enzymes, intermediate metabolites and inorganic phosphate and it can precipitate DNA [12]. In general, the biological activities of La3+ on a cellular system is often mediated through the competition for binding sites with calcium ions, since both ions have similar ionic radii [11] and also through its high affinity for phosphate groups of biological molecules.

As indicated above, only a few aquatic toxicological studies addressing environmental effects of La in invertebrates have been published. Therefore, there is clearly a lack of data on the potential Sublethal and long term effects of REEs in aquatic organisms. Biochemical approaches in ecotoxicology have the advantage of finding early warning signals at the molecular level, which can led to effects at higher levels of biological organization [32]. Moreover, the study of biomarkers at different levels of the biological scale allows to elucidate adverse outcome pathways and a better understanding of the mechanisms involved on species [33]. Bivalves are one of animal models that are often used to conduct ecotoxicological studies with biomarkers [34]. Those animals are important members of aquatic invertebrates and have essential ecological functions as food source, calcium mobilization and removal of suspended matter in the water column. Moreover, these organisms are efficient filter feeders which exposed them to numerous contaminants, including REEs. Among bivalves, zebra mussel Dreissena polymorpha, a wellestablished invasive model organism has been frequently used in Europe as well as in North America for the biomonitoring and for the assessment of environmental quality [35]. Indeed, those mollusks which pervade most environments with enough calcium and zooplankton to sustain their growth and survival are widespread and found in nearly all water bodies in Europe and North America.

Thus, the purpose of this study was to investigate the effect of a sub chronic exposure to $\mathrm{LaCl}_{3}$ in a freshwater invertebrate, the zebra mussel Dreissena polymorpha. La concentrations were determined in mussel tissues to assess its bioavailability. In addition to bioavailability; biomarkers of oxidative and genetic damage were evaluated through a multi biomarker approach. Biomarkers studied in this work were selected given that previous reports revealed cytotoxicity following overproduction of reactive oxidative species (ROS) leading to lipid peroxidation, and DNA damage.

\section{Materials and methods}

\section{Sampling}

Adult zebra mussels, Dreissena polymorpha, were collected in July 2014 at a reference site in the Saint-Lawrence River near the City of Montréal, Québec, Canada at the following coordinates $45^{\circ} 19^{\prime} 50^{\prime \prime} \mathrm{N}, 73^{\circ} 58^{\prime} 12^{\prime \prime}$ W.Mussels were gently cut off from the rocks (they attached themselves to solid substrates through abyssus), quickly transferred to the laboratory in bags filled with river water. For acclimation, mussels were kept in $50 \mathrm{~L}$ glassholding aquaria filled with charcoal and UV-treated tap water (City of Montréal, QC. Canada) in the laboratory at $15^{\circ} \mathrm{C}, 16 \mathrm{~h}$ light/8h dark cycle under constant aeration and were fed three times per week with concentrates of phytoplankton (Phytoplex, Kent Marine, WI) and Pseudokirchneriella subcapitata algal preparations. A total of 240 mussels having similar shell length $(1.3 \pm 5 \mathrm{~mm})$ were used in this study. Mussels were placed in $4 \mathrm{~L}$ containers lined with polyethylene bags and exposed to increasing concentrations $(10,50,250$ and $1250 \mu \mathrm{g} / \mathrm{L})$ of lanthanum chloride $\left(262072\right.$, Sigma) for 14 and 28 days at $15^{\circ} \mathrm{C}$. The control group consisted of mussel exposed to aquarium water only. The number of mussels used was 24 for each group. After exposure periods, tissues from a sub-group of mussel ( $\mathrm{n}=8$ mussels/ treatment) were collected for subsequent biomarker assays and for evaluation of total La accumulation ( $\mathrm{n}=8$ mussels/treatment). Another sub-group of survival mussel ( $\mathrm{n}=8$ mussels/treatment) was removed and used to evaluate the air-time survival i.e., the survival of mussels in air.

\section{Chemical analyses}

The bioavailability of La was determined in water and in the soft tissue of mussels. La concentrations in water samples from control and exposure groups were analyzed at the beginning of the exposure period $(\mathrm{t}=0)$. Briefly, total La concentrations were determined after acidification with nitric acid (1\%) (seastar grade) and analyzed by ion-coupled plasma mass spectrometry (ICP-MS, XSERIES 2 ICP-MS, Thermo Scientific, USA)with a detection limit of $1 \mathrm{ng} / \mathrm{L}$.

Bioaccumulation of La was carried out at the end of exposure periods after keeping mussel in clean water for $24 \mathrm{~h}$ to allow them to depurate. Soft tissue was sampled, weighed and frozen at $-80^{\circ} \mathrm{C}$ until analysis. Tissues were acid-digested with $8 \mathrm{ml}$ of concentrated $\mathrm{HNO}_{3}, 1 \mathrm{ml}$ of concentrated $\mathrm{HCl}$, and $2 \mathrm{ml}$ of concentrated $\mathrm{H}_{2} \mathrm{O}_{2}$. The tissues were then digested during $2 \mathrm{~h}$ at $170^{\circ} \mathrm{C}$ using a high pressure microwave oven (Ethos EZ, Milestone Scientific Inc, ON, Canada). The samples were completed to final volume of $12 \mathrm{ml}$ with de ionized water. Total La concentration was afterwards determined by ICP-MS (XSERIES 2 ICP-MS, Thermo Scientific, USA) with a detection limit of $0.02 \mathrm{mg} / \mathrm{Kg}$ (wet/weight). The metal bioaccumulation factor (BAF) was calculated by dividing the mean level of metals in soft tissues by the total mean values for metals found in the dissolved and particle-bound phases.

\section{Air time survival}

After 14 and 28 days of exposure to La, the survival of mussels in air was evaluated. This experience was performed for up to 7 days in air at $20^{\circ} \mathrm{C}$ under humidified atmosphere ( $\left.>80 \%\right)$. Mortality was determined by sustained shell opening and total weight was recorded each day for 7 days. The proportions of weight loss were calculated by the following formula: \% weight 
loss $=($ (mussel weight at the end of exposure to air / mussel weight before exposure to air) x 100)-100.

\section{Biochemical analyses}

Mussels were thawed on ice for approximately 10-15 min. After rapid dissection, soft tissue from each mussel was homogenized in 1:5 $(\mathrm{w} / \mathrm{v})$ ratio of buffer solution containing25 $\mathrm{mM}$ Hepes-NaOH buffer, $100 \mathrm{mM} \mathrm{NaCl}, 1 \mathrm{mM}$ dithiothreitol and $1 \mu \mathrm{g} / \mathrm{L}$ of aprotinin with $\mathrm{pH}$ adjusted to 7.4. Aliquots of each homogenate were sampled for total protein lipid peroxidation (LPO), DNA damage (DNA). A portion of the homogenates was centrifuged at $1500 \mathrm{~g}$ for $10 \mathrm{~min}$ at $2^{\circ} \mathrm{C}$ and the resulting supernatant, considered free of unbroken cells or cell debris, was centrifuged at $10000 \mathrm{~g}$ for $20 \mathrm{~min}$ at $2^{\circ} \mathrm{C}$ and collected for determination of metallothionein (MT) levels and glutathione S-transferase (GST) activity. The pellet was re-suspended in homogenization buffer $(200 \mu \mathrm{L} / \mathrm{g}$ of tissue) and used as a mitochondrial fraction to measure the citrate synthase activity. The supernatant (S10), the mitochondrial fraction and the homogenates were stored at $-80^{\circ} \mathrm{C}$ until analysis. Concentrations of studied biomarkers were normalized with the total individual protein concentration according to Bradford methodology [36] with bovine serum albumin as the standard. Total protein concentration was measured with the absorption at $595 \mathrm{~nm}$ by a micro plate reader.

Lipid peroxidation: Lipid peroxidation (LPO) was determined according to the thiobarbituric acid (TBARS) methodology (Wills, 1987) which consists to measure the production of malonaldehyde in the mussel homogenate. A volume of $150 \mu \mathrm{L}$ of $10 \%$ TCA containing $1 \mathrm{mM} \mathrm{FeSO}_{4}$ and $75 \mu \mathrm{L}$ of $0.67 \%$ TBA was added to $75 \mu \mathrm{L}$ of homogenate, mixed and heated at $70^{\circ} \mathrm{C}$ for $10 \mathrm{~min}$. To detect thiobarbituric acid reactants, $100 \mu \mathrm{L}$ of the supernatant was added to a 96 well plate and fluorescence was measured at 540 and $600 \mathrm{~nm}$ for excitation and emission, respectively. Blanks and standards of tetramethoxypropane (stabilized form of malonaldehyde) were prepared in the presence of the homogenization buffer. The data were expressed as nmoles of TBARS/ mg of homogenate proteins.

DNA damage: The levels of DNA strand breaks were determined using the alkaline precipitation assay developed by [37] but using fluorescent-based DNA strands for detection. The assay principle is based on the precipitation of proteincontaining genomic DNA from protein-free DNA strand breaks left in the supernatant. $200 \mu \mathrm{L}$ of $2 \%$ SDS, $10 \mathrm{mM}$ EDTA, $10 \mathrm{mM}$ Tris and $40 \mathrm{mM} \mathrm{NaOH}$ and $200 \mu \mathrm{L}$ of $0.12 \mathrm{M} \mathrm{KCl}$ were added to $25 \mu \mathrm{L}$ of homogenate than mixed and heated at $60^{\circ} \mathrm{C}$ for $10 \mathrm{~min}$. Samples were removed, kept at $4^{\circ} \mathrm{C}$ for 30 min and centrifuged at $8000 \mathrm{~g}$ for $5 \mathrm{~min}$ at $4^{\circ} \mathrm{C}$. A $50 \mu \mathrm{L}$ sample of the supernatant was added to a 96 well plate and DNA strands were detected using the Hoechst dye at $350 \mathrm{~nm}$ excitation and $450 \mathrm{~nm}$ emission. DNA quantification was measured with standard solutions of salmon sperm DNA. The data were expressed as $\mu \mathrm{g}$ DNA/ mg proteins in the homogenate.

Glutathione S-transferase activity: Glutathione S-transferase (GST) was measured using 1-chloro-2,4-dichloronitroben- zene (CDNB) as substrate. The reaction mixture containing $10 \mathrm{mM}$ Hepes pH 6.5, 1mM GSH, 1mM 1-chloro-2-4-dinitrobenzene, 125 $\mathrm{mM} \mathrm{NaCl}$. The absorbance was measured at $340 \mathrm{~nm}$ and standard solutions of freshly prepared GSH were used for calibration. The results were expressed as formation of nmoles of GSH per minute per milligram protein (nmoles $\mathrm{GSH} / \mathrm{min} / \mathrm{mg}$ proteins).

Citrate synthase activity: Citrate synthase (CS) activity was determined using a spectrophotometric assay in the mitochondrial fraction according to the method described by [38] with slight modifications. Briefly, $10 \mu \mathrm{L}$ of oxaloacetate (final concentration of $0.5 \mathrm{mM}$ ) was mixed to $10 \mu \mathrm{l}$ of mitochondrial preparation and $180 \mu \mathrm{l}$ of assay buffer $(100 \mathrm{mM}$ Tris-HCl pH 8, $0.4 \mathrm{mM}$ Acetyl CoA, 0.2mM 5,5-dithio-bis-(2-nitrobenzoic acid)(DTNB).The assay was performed in a microplate reader for $30 \mathrm{~min}$ at $412 \mathrm{~nm}$ and $25^{\circ} \mathrm{C}$. Activities were determined by the following formula: $\Delta$ absorbance / $\mathrm{min} /$ ( $\varepsilon \mathrm{x} \mathrm{L}(\mathrm{cm}) \mathrm{x} \mathrm{mg}$ mitochondria); $\varepsilon$ : is the extinction coefficient of DTNB at $412 \mathrm{~nm}$ (13.6 $\mathrm{mM} \mathrm{cm--1)} \mathrm{and} \mathrm{L}$ : is the path length for absorbance.

Metallothionein-like proteins (MT): The level of MT like proteins was measured by the silver saturation assay [39] using the modification for non-radioactive silver [40]. A $50 \mu \mathrm{L}$ subsample of the $10000 \mathrm{~g}$ supernatant was mixed with one volume of $0.2 \mathrm{M}$ glycine buffer ( $\mathrm{pH} 8.5$ ) and $\mathrm{Ag}$ was added to obtain a final concentration of $2 \mathrm{mg} / \mathrm{L}$ at $\mathrm{pH} 8.5$ in glycine buffer. After incubation for 15 minatroom temperature, $25 \mu \mathrm{L}$ of $2.5 \%$ hemoglobin $(\mathrm{Hb})$ was added and incubated for $5 \mathrm{~min}$ at $20 \mathrm{oC}$. The sample was then heated at $100^{\circ} \mathrm{C}$ for $2 \mathrm{~min}$ and centrifuged at $10000 \mathrm{~g}$ for $5 \mathrm{~min}$ to remove excess silver bound to denatured proteins and added hemoglobin. The last step was repeated once more to completely remove the excess (loosely bound) silver. The silver concentration in the supernatant was determined by atomic absorption spectrophotometry equipped with Zeeman effect background correction. A ratio of 12 moles of bound Ag to 1 mole of MT was assumed [41]. Results were expressed as nmoles of MT equivalents/ mg of proteins.

\section{Data analysis}

Data were expressed as mean \pm standard error and normality was checked with Kolomogorov-Smirnov' test. Analysis of variance (ANOVA), was followed by a Fisher LSD post-hoc test to evaluate significant differences $\left(*: p<0.05\right.$; $\left.{ }^{* *}: p<0.01\right)$ between treated samples and controls. The Pearson correlation was carried out to examine the global response patterns of biomarkers and bioaccumulation data between control and exposed groups. All the statistical analyses were conducted with STATISTICA (version 7, statsoft Inc., 1995)

\section{Results}

\section{Lanthanum bioavailability}

At $\mathrm{t}=0$, La concentrations in water were approximately 15$30 \%$ lower than expected in the $10-1250 \mu \mathrm{g} / \mathrm{L}$ range of test concentrations (table1). In the soft tissue, La contents determined after both times of exposure showed a concentration dependent significant increase compared with the control mussels in which La was detected at trace levels (table 1). The concentration of 
Table 1: La concentrations measured by ICP MS in water at $\mathrm{t}=0$ and in the soft tissue of zebra mussel exposed to LaCl ${ }_{3}$ for 14 and 28 days. Variations of bio concentration factors of La in mussel were also reported. The data represent the mean \pm standard error ( $\mathrm{n}=8$ ), $p$ values were determined by ANOVA. Fisher LSD post-hoc test was used to identify significant differences between La treatments and control (Ctrl) $\left({ }^{*} p<0.05,{ }^{* *} p<0.01\right.$ level).

\begin{tabular}{|c|c|c|c|c|c|}
\hline \multirow[t]{2}{*}{ La concentration $(\mu \mathrm{g} / \mathrm{L})$} & \multirow{2}{*}{$\begin{array}{c}\text { La biavailability in water } \\
(\mu \mathrm{g} / \mathrm{L})\end{array}$} & \multicolumn{2}{|c|}{$\begin{array}{l}\text { La biavailability in tissue } \\
(\mathrm{mg} / \mathrm{Kg})\end{array}$} & \multicolumn{2}{|c|}{$\begin{array}{l}\text { BAF } \\
(\mathrm{L} / \mathrm{Kg})\end{array}$} \\
\hline & & $t=14$ days & $t=28$ days & $\mathrm{t}=14$ days & $\mathrm{t}=\mathbf{2 8}$ days \\
\hline $\mathbf{0}$ & $0.0074 \pm 0.0005$ & $0.048 \pm 0.012$ & $0.039 \pm 0.001$ & 6553,41 & 5275,75 \\
\hline 10 & $8.68 \pm 1.6$ & $1.31 \pm 0.17$ & $1.81 \pm 0.47$ & 151,73 & 209,02 \\
\hline 50 & $36.97 \pm 5.13$ & $5.19 \pm 0.7$ & $5.97 \pm 0.79^{*}$ & 140,49 & 161,43 \\
\hline 250 & $212.57 \pm 54.65$ & $21.46 \pm 8.5^{*}$ & $15.58 \pm 2.47^{* *}$ & 100,96 & 73,30 \\
\hline 1250 & $1042.77 \pm 162.97$ & $51.66 \pm 6.26^{* *}$ & & 49,54 & \\
\hline
\end{tabular}

metal accumulated in the tissue after exposure to the highest dose of La was determined only after 14 days of exposure as we have observed mortality in mussels after prolonged exposure of 28 days. The amount of La accumulated after 14 days of exposure to $1250 \mu \mathrm{g} / \mathrm{L}$ reached a value significantly higher than the control ( $p<0.0001), 51.65 \mathrm{mg} / \mathrm{Kg}$ (wet/weight) and giving a La bioaccumulation factor (BAF) of $49 \mathrm{~L} / \mathrm{Kg}$. Whereas, no significant differences could be evidenced between groups exposed to the lower concentrations of La (10 and $50 \mu \mathrm{g} / \mathrm{L})$ and the control $(p<0.05)$.

After 28 days of exposure, results showed no significant differences between groups treated with the lowest dose and the control one $(\mathrm{p}>0.05)$. However, La concentrations were 150 fold $(p<0.05)$ and 400 fold higher $(p<0.0001)$ than the control mussels for mussels exposed respectively to 50 and $250 \mu \mathrm{g} / \mathrm{L}$. The BAFs for the mussels exposed to those concentrations were 161 and 73L/Kg respectively. Moreover, comparing to results obtained after 14 days of treatment, concentration of La detected in mussels treated with $250 \mu \mathrm{g} / \mathrm{L}$ was lower.

\section{Air-time survival in freshwater mussels}

In order to understand the cumulative effects of chronic exposure to La and air exposure, the air-time survival test was determined. The survival of mussels was assessed by evaluating the capacity of mussels to maintain closed shells as it is known that bivalve shells remain closed during stressful situations. Data showed that air time survival was not affected in all groups treated with La by comparison to control (Figure 1A). Overall, mortality occurred after 4 days of exposure to air but after 6 days of exposure mussel shells remain closed. Our results also indicated that mortality in the group treated with the highest concentration of La for 14 days occurs with less body weight loss $30 \%$ by comparison to control group $41 \%(p<0.05)$ (Figure 1B). While after 28 days and for the same dose, body weight loss leading to mortality (31\%) was higher than in control group $(25 \%)$ suggesting that rapid weight loss precedes mortality events. For the other groups of mussels, the body weight loss was not significantly affected ( $p>0.05)$.

\section{Biochemical effects}

Biomarker results are reported in Figure 2. Oxidative damage was determined in mussel tissues by following changes in LPO.
After 14 days, La caused a significantly concentration dependent decrease in LPO levels (Figure 2A).Exposure to La 250 and $1250 \mu \mathrm{g} / \mathrm{L}$ induced a significant decrease of TBARS amount by $31 \%(p<0.05)$ and $46 \%(p<0.001)$ compared respectively to the concentration measured in control group. In contrast, a significant increase of LPO was found after 28 days of exposure to $1250 \mu \mathrm{g} / \mathrm{L}$ $(p<0.01)$, with values $80 \%$ higher than the corresponding control. In contrast, no significant differences were evidenced between the other tested doses and control.

DNA strand breaks (Figure 2B) and MT (Figure 2D) levels in Dreissena polymorpha tissues showed no significant differences between all treatments $(p>0.05)$ with respect to the control at either exposure times (14 and 28 days).The increase in LPO observed after 28 days was not correlated with DNA strand breaks( $r=0.2, p>0.05$ ) (table 3 ) suggesting that LPO increase did not affect the DNA repair process and that La is not genotoxic. Our results, showed also that after both times of exposure, no significant variations in GST activity were observed at concentrations up to $250 \mu \mathrm{g} / \mathrm{L}$ with respect to the control $(p>0.05)$. However, a significant decrease in GST activity (Figure 2C) was observed at $1250 \mu \mathrm{g} / \mathrm{L}$ after14 days but not after 28 days of exposure. A correlation analysis revealed that GST activity after 28 days was correlated to DNA strand breaks $(\mathrm{r}=0.4, p<0.05)$ and MT level $(r=0.54, p<0.05)$ (table 3$)$, but no correlation was found after 14 days of exposure (table 2). The citrate synthase activity (Figure 2E) showed a significant increase with the lowest concentration of Lain respect to the control group ( $p<0.05)$, after both times of exposure. In contrast, no significant differences were evidenced with the two highest concentrations tested but a trend to decrease could be noticed after 28 days of treatment.

\section{Discussion}

The toxicological understanding of REEs in the aquatic environment is very limited but of increasing concern. There are several potential mechanisms by which the REEs may exert toxicity on aquatic organisms; however the exact mode of action remains unknown. In order to elucidate the mechanism of action of La, we have determined its bioavailability in water and mussel tissues and examined the oxidative stress and antioxidant/ detoxifying systems status in zebra mussel after chronic exposure.

This study revealed that the amount of La markedly increased in zebra mussel tissues. This finding was in accordance with 

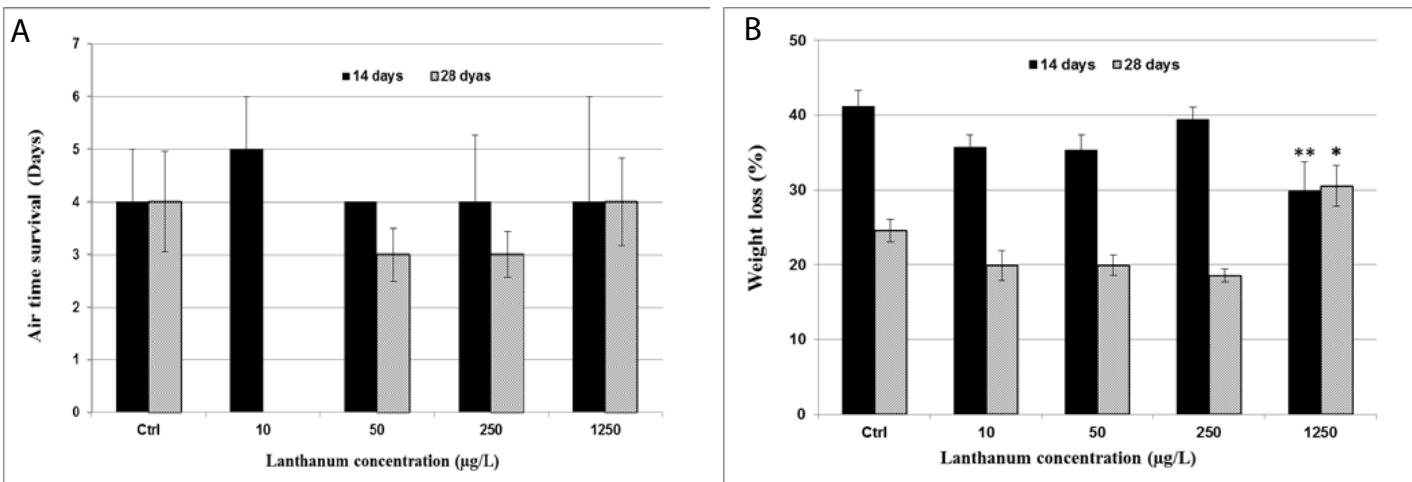

Figure 1: Evaluation of the air time survival (A) and weigh loss of mussels (B) after treatment with La and exposure to air for 7 days. The air-time survival represents the number of days required to die as evidenced by constant shell opening. Data represent the mean with the standard error $(n=8)$. Pvalues were determined by ANOVA followed by a Fisher LSD post-hoc test to identify significant differences between La treatments and control $(* p<0.05, * * p<0.01)$.
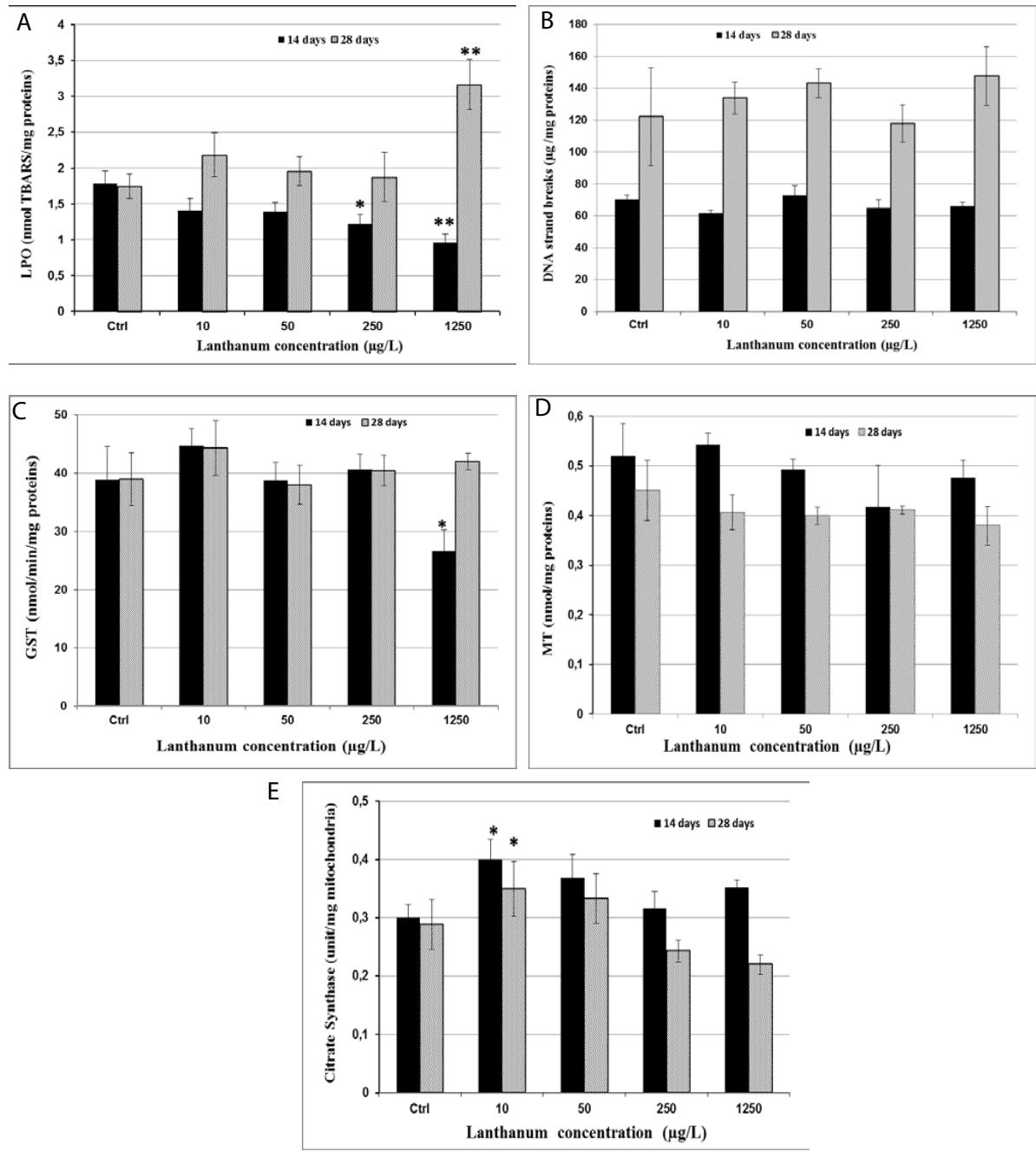

Figure 2: Biomarkers in zebra mussel tissue exposed for 14 and 28 days to different concentrations of LaCl. Lipid peroxidation amount (LPO: A), DNA strand breaks level (B), glutathione S-transferase activity (GST: C), metallothionein level (MT: D) and citrate synthase activity (E). Data represent the mean with the standard error $(\mathrm{n}=8)$. The asterisks indicate a significant difference from the controls $\left({ }^{*} p<0.05 ;{ }^{* *} p<0.01\right.$, ANOVA followed by a Fisher LSD post-hoc test).. 
Table 2: Pearson correlations calculated between biomarkers analyzed after 14 days of exposure $(\mathrm{LPO}=$ lipid peroxidation, APA= DNA strand breaks, GST = glutathione S-transferase, $\mathrm{MT}=$ metallothioneins, $\mathrm{CS}=$ citrate synthase) and La bioaccumulation (Bio) data.

\begin{tabular}{|c|c|c|c|c|c|c|c|}
\hline & LPO & APA & Bio & GST & MT & CS & Weight loss \\
\hline LPO & 1 & & & & & & \\
\hline APA & 0.20 & 1 & & & & & \\
\hline Bio & -0.27 & 0.32 & 1 & & & & \\
\hline GST & 0.31 & 0.05 & -0.17 & 1 & & & \\
\hline MT & 0.06 & 0.24 & -0.12 & -1.80 & 1 & & \\
\hline CS & -0.16 & 0.02 & -0.01 & -1.93 & 0.09 & 1 & \\
\hline Weight loss & 0.22 & 0.08 & -0.28 & -0.02 & 0.09 & 0 & 1 \\
\hline
\end{tabular}

Table 3: Pearson correlations calculated between biomarkers analyzed after 28 days of exposure $(\mathrm{LPO}=$ lipid peroxidation, APA= DNA strand breaks, GST = glutathione S-transferase, $\mathrm{MT}=$ metallothioneins, $\mathrm{CS}$ = citrate synthase) and La bioaccumulation (Bio) data. The asterisks represent a significant difference $\left({ }^{*} p<0.05 ;{ }^{* *} p<0.01\right)$.

\begin{tabular}{|c|c|c|c|c|c|c|c|}
\hline & LPO & APA & Bio & GST & MT & CS & $\begin{array}{c}\text { Weight } \\
\text { loss }\end{array}$ \\
\hline LPO & 1 & & & & & & \\
\hline APA & 0.18 & 1 & & & & & \\
\hline Bio & -0.26 & 0.16 & 1 & & & & \\
\hline GST & 0.02 & $0.40^{*}$ & 0.25 & 1 & & & \\
\hline MT & -0.23 & 0.24 & -0.16 & $0.54^{* *}$ & 1 & & \\
\hline CS & 0.04 & 0.09 & -0.10 & 0.17 & 0.22 & 1 & \\
\hline Weight loss & -0.15 & 0.02 & -0.16 & 0.05 & 0.24 & -0.10 & 1 \\
\hline
\end{tabular}

previous field study showing a higher bioaccumulation of La in these aquatic organisms [42]. However, the BAF value (32,000 L/ $\mathrm{Kg}$ ) reported by these authors was greater than that calculated in the current study. This could be explained by differences in the exposure method which may greatly affects the concentration and the bioavailability of La. Moreover, our results showed that BAFs decreased with increased concentration of La and no further accumulation of La was found in mussel exposed to $250 \mu \mathrm{g} / \mathrm{L}$ for 28 days compared to those treated with the same dose for 14 days. This may be due to the maintenance of regulatory mechanisms that limit their accumulation (e.g., excretory pathways and/or uptake limitation) [43].

According to biomarkers responses, no tissue damage was observed after 14 days of exposure to La as revealed by LPO levels. However, at the end of 28 days of exposure, this element induced significant increase of LPO suggesting the involvement of the reactive oxygen species (ROS) in the mechanism of La toxicity. Our finding was consistent with previous studies showing that $\mathrm{LaCl}_{3}$ exposure promoted ROS production in the mouse lung [44] and in the brains of the mice [45], which in turn resulted in peroxidation of lipids. However, this also was in agreement with studies indicating that $\mathrm{LaCl} 3$ plays a protective role by inhibiting $\mathrm{H}_{2} \mathrm{O}_{2}$ induced elevation in ROS level in rat calcifying vascular cells [46]. Thus, it appears that La may have two kinds of action, an antioxidant and a prooxidant effect depending on the concentration and the duration of exposure. Paiva et al. (2009) indicated that pretreatment of Jurkat cells with Trolox, a known free radical scavenger, leads to a significant decrease of DNA damages in cells incubated with La (NO3)3. Therefore, they suggested that oxidative stress may be involved in the genotoxic process induced by La. However, no genotoxic effect of La could be evidenced in our work after both times of exposure. This was in agreement with studies performed by [47], showing that RE ions at concentration of $1000 \mu \mathrm{M}$ did not induce genotoxicity. ROS scavenging by $\mathrm{LaCl}_{3}$ observed after 14 days could in turn explain the absence of DNA strand breaks. Indeed, low concentrations of antioxidants drive ROS levels to an optimal "physiological range", which reduces oxidative stress induced DNA damage without impairing the DNA repair system [48].

An antioxidant effect played by cerium was also reported in the literature and authors suggested that this lanthanide could scavenge ROS and act as a catalyst miming and improving the activity of SOD and catalase $[49,50]$. The role of La in suppressing $\mathrm{H}_{2} \mathrm{O}_{2}$ 's effects might be played through calcium signaling as it acts as a $\mathrm{Ca}^{2+}$ antagonist [51] and a calcium channel blocker [46]. Indeed, lanthanides can compete with $\mathrm{Ca}^{2+}$ in ion and channel binding sites due to their similar properties to $\mathrm{Ca}^{2+}$, since both ions have similar ionic radii but not the same charge. The involvement of calcium in the mechanism of action of $\mathrm{LaCl}_{3}$ is controversial because other studies indicated that lanthanides bound to $\mathrm{Ca}^{2+}$ binding proteins decrease the Ca content into the cell and generate an excess of extracellular calcium, leading to oxidative stress production $[3,45]$. It was also reported that blocking of intracellular $\mathrm{Ca}^{2+}$ influx by $\mathrm{GdCl}_{3}$ induced suppression of GST gene expression [52]. Pre- and post-treatment of freshwater catfish exposed to fluoride with ascorbic acid, which exhibit good antioxidant and free-radical scavenging activities, lead to the decrease of LPO and GST level in the liver and ovary tissues [53]. Thus, the decreased GST activity observed with the highest dose could be explained by gene down regulation resulting from decreased $\mathrm{H}_{2} \mathrm{O}_{2}$ contents and the imbalance of calcium level in mussel's tissue. Taken together, it is possible that oxidative stress is mediated by calcium in zebra mussels which is calcium sensitive species for growth and shell generation.

It is well known that MT induction is enhanced by an increase in the availability of divalent essential metals $(\mathrm{Cu}$ and $\mathrm{Zn})$ and non-essential metals ( $\mathrm{Cd}, \mathrm{Ag}$ and $\mathrm{Hg}$ ). In the present study, La bioaccumulation in the tissue of zebra mussel did not trigger MT induction which suggests that La remains trivalent or is strongly bound to other sites. This result is not consistent with those obtained for Tetrahymena thermophila cells showing that La induced the expression of MT [54]. MT induction was also reported by Kobayashi et al. [55] after administration of cerium chloride to mice. In those studies analysis of MT induction was performed under short exposure times to lanthanides. Amirad et al [56]. Indicated that the time periods of contamination affect the induction of MT and Barka et al. [57] confirmed that in the copepod T. brevicornis, cadmium induced MT on the first day of exposure, but not in the following days. Thus, it is possible that 
MT induction occurred after short time of exposure to La but it did not play a main role in the detoxification or homeostasis of this trivalent metal after chronic exposure.

CS activity is one of the key regulatory enzymes in the tricarboxylic acid (TCA) cycle [58] and it was extensively used as a metabolic marker in assessing oxidative, mitochondrial abundance and respiratory capacity [59]. Our results showed that low concentration of La enhanced citrate synthase activity which indicated that this lanthanide increase the TCA cycle. A recent study showed that lead exposure caused a substantial increase in the ADP/ATP ratio in the hippocampus of rats and this change is restored by $\mathrm{CeO}_{2}$ and or $\mathrm{Y}_{2} \mathrm{O}_{3}[60]$. They suggested that increase of ATP can be through decrease of oxidative stress and thereby improvement of mitochondrial function and respiratory chain However, previous studies have indicated that decreases in the activities of CS induced oxidative stress [61, 62]. Those findings are in accordance with our results because with the highest concentration, citrate synthase activity tends to decrease at the end of exposure time. The depletion of citrate synthase activity could be explained by the formation of a complex with certain carboxylic acids as suggested for $\mathrm{Gd}^{3+}[63]$.

Our results showed that mussel exposed to prolonged periods to air did not show significant decrease in air-time survival and mussel weight in groups exposed to air after treatment with La compared to a control group. Exposure of freshwater mussels to prolonged periods of air leads to important physiological changes in the attempt to survive outside of water [64]. During this period, mussels expend metabolic energy under low oxygen tension, leading to increased anaerobic metabolism and loss of energy reserves [64]. Occurrence of anaerobic glycolysis was also reported when bivalves are exposed to environment pollutant. It was indicted that phoxim poisoning was reduced in larvae of B. mori via deriving some energy from anaerobic glycolysis. However, added $\mathrm{CeCl}_{3}$ lead to decreased phoxim toxicity by improving TCA cycle, meeting the required energy demands and therefore increase survival rate of larvae under phoxim toxicity [65]. Thus, we suggested that $\mathrm{LaCl}_{3}$ may contribute to the resistance of mussel to air exposure by suppressing anaerobic metabolism and improving TCA cycle which lead to increasing energy supply and survival rate.

\section{Conclusion}

Investigations on the bioaccumulation and biochemical effects of lanthanides can be of particular interest to elucidate their effects on aquatic organisms. Data showed that La concentration markedly increased in mussel tissues. However, no further accumulation of La was detected after 28 days of exposure, suggesting the existence of regulatory mechanism that limits its accumulation. Based on the multi biomarker approach, the presence of La in the environment does not seem to present a risk to aquatic ecosystems except at some hotspots or for peak concentrations. Indeed, no strong adverse effects of La were observed after 14 days of exposure as it acts as an antioxidant. By contrast, a prooxidant effect was evidenced after 28 days in mussels exposed to the highest concentration. However, this study was conducted under controlled condition and the possibility of cumulative effects in more complex environmental conditions could not be excluded. Therefore, this work confirms the relevance of studying the effect of this lanthanide under chronic exposure but complementary studies should be performed under different scenarios to estimate potential future risks in a long term perspective. Investigations of the different pathways involved in the mechanism of action of this lanthanide, particularly those related to calcium are required for better understanding of its effects. Furthermore, co-exposure with prooxidant substances should be conducted to confirm the potential antioxidant properties of this lanthanide observed after 14 days.

\section{Acknowledgments}

We thank the Natural Sciences and Engineering Research Council of Canada (NSERC) and the Chemical Management Plan (CMP) of Environment Canada for their financial support.

\section{Reference}

1. Gonzalez V, Vignati DAL, Leyval C, Giamberini L. Environmental fate and ecotoxicity of lanthanides: Are they a uniform group beyond chemistry? Environ Int. 2014;71:148-157. doi: 10.1016/j. envint.2014.06.019

2. Du X, Graedel TE. Uncovering the Global Life Cycles of the Rare Earth Elements. Sci Rep. 2011;1:145. doi:10.1038/srep00145

3. Wu J, Yang J, Liu Q, Wu S, Ma H, Cai Y. Lanthanum Induced Primary Neuronal Apoptosis Through Mitochondrial Dysfunction Modulated by Ca2+ and Bcl-2 Family. Biol Trace Elem Res. 2013;152(1):125-134. doi: 10.1007/s12011-013-9601-3

4. González V, Vignati DAL, Pons M-N, Montarges-Pelletier E, Bojic C,Giamberini L. Lanthanide ecotoxicity: First attempt to measure environmental risk for aquatic organisms. Environ Pollut. 2015;199:139-147. doi: 10.1016/j.envpol.2015.01.020

5. Kulaksız S, Bau M. Rare earth elements in the Rhine River, Germany: First case of anthropogenic lanthanum as a dissolved micro contaminant in the hydrosphere. Environ Int. 2011;37(5):973-979. doi: 10.1016/j.envint.2011.02.018

6. Li N, Wang S, Liu J, Ma L, Duan Y, Hong F. The Oxidative Damage in Lung of Mice Caused By Lanthanoide. Biol. Trace Elem. Res. 2010; 134(1): 68-78. doi: 10.1007/s12011-009-8448-0

7. Paiva AV, de Oliveira MS, Yunes SN, de Oliveira LG, Cabral-Neto JB, de Almeida CE. Effects of Lanthanum on Human Lymphocytes Viability and DNA Strand Break. Bull. Environ. Contam. Toxicol. 2009; 82(4):423-427. doi: 10.1007/s00128-008-9596-1

8. Yang J, Liu Q, Qi M, Lu S, Wu S, Xi Q, et al. Lanthanum chloride promotes mitochondrial apoptotic pathway in primary cultured rat astrocytes. Environ Toxicol. 2013;28(9):489-497. doi: 10.1002/tox.20738

9. Pałasz A, Czekaj P. Toxicological and cytophysiological aspects of lanthanides action. Acta Biochim Pol. 2000;47(4):1107-1114.

10. Feng L, Xiao H, He X, Li Z, Li F, Liu N, et al. Neurotoxicological consequence of long-term exposure to lanthanum. Toxicol Lett. 2006;165(2):112-120. doi: 10.1016/j.toxlet.2006.02.003

11. Herrmann H, Nolde J, Berger S, Heise S. Aquatic ecotoxicity of lanthanum - A review and an attempt to derive water and sediment quality criteria. Ecotoxicol Environ Saf. 2016;124:213-238. doi: 10.1016/j.ecoenv.2015.09.033 
12. Das T, Sharma A, Talukder G. Effects of lanthanum in cellular systems. A review. Biol Trace Elem Res. 1988;18:201-228.

13. Tomlinson G, Mutus B, McLennan I, Mooibroek MJ. Activation and inactivation of purified acetylcholinesterase from Electrophorus electricus by lanthanum (III). Biochim Biophys Acta. 1982; 703(2): 142-148.

14. Tokimasa T, North RA. Effects of barium, lanthanum and gadolinium on endogenous chloride and potassium currents in Xenopus oocytes. ] Physiol. 1996;496(Pt 3):677-686.

15. Hardy MA, Balsam P, Bourgoignie JJ. Reversible inhibition by lanthanum of the hydrosmotic response to serosal hypertonicity in toad urinary bladder. J Membr Biol. 1979;48(1): 13-19.

16. Mellanby J, Thompson PA. The interaction of tetanus toxin and lanthanum at the neuromuscular junction in the goldfish. Toxicon. 1981; 19(4):547-554.

17. Miledi R, Molenaar PC, Polak RL. The effect of lanthanum ions on acetylcholine in frog muscle. J Physiol. 1980;309:199-214.

18. Mellanby J, Beaumont MA, Thompson PA. The effect of lanthanum on nerve terminals in goldfish muscle after paralysis with tetanus toxin. Neuroscience. 1988; 25(3):1095-1106.

19. Cui J ZZ, Bai W, Zhang L, He X, Ma Y, Liu Y, et al. Effects of rare earth elements La and $\mathrm{Yb}$ on the morphological and functional development of zebrafish embryos. J Environ Sci (China). 2012;24(2): 209-213.

20. Barry MJ, Meehan BJ. The acute and chronic toxicity of lanthanum to Daphnia carinata. Chemosphere. 2000;41(10): 1669-1674.

21. Bogers M. Daphnia Magna, reproduction test with Lanthanum (La). Report No.: 139499. Testing Laboratory: NOTOX. B. V.'sHertogenbosch, The netherlands. Owner company : Kemira Pernis B. V, ‘s-Hertogenbosch, Rotterdam. 1995.

22. Stauber JL, Binet MT. Canning River Phoslock Field Trial - Ecotoxicity Testing Final Report, Report No: ET317R, CSIRO Centre for Advanced Analytical Chemistry Energy Technology, Australia 2000.

23. Stefano GB, Brogan JJ, Aiello E, Hiripi L. Lanthanum blockade of serotonin release from the branchial nerve of the mussel Mytilus edulis. J Exp Zool. 1980;214(1):21-26.

24. Muneoka Y, Twarog BM. Lanthanum block of contraction and of relaxation in response to serotonin and dopamine in molluscan catch muscle. J Pharmacol Exp Ther. 1977;202(3):601-609.

25. Brink PR, Kensler RW, Dewey MM. The effect of lanthanum on the nexus of the anterior byssus retractor muscle of Mytilus edulis L. Am J Anat. 1979;154(1):11-26.

26. Valcheva-Traykova M, Saso L,Kostova I. Involvement of lanthanides in the free radicals homeostasis. Curr Top Med Chem. 2014; 14(22):2508-2519.

27. He X, Zhang Z, Zhang H, Zhao Y, Chai Z. Neurotoxicological Evaluation of Long-Term Lanthanum Chloride Exposure in Rats. Toxicological Sciences. 2008;103(2):354-361. DOI: 10.1093/toxsci/kfn046

28. Che Y, Cui Y, Jiang X. Effects of Lanthanum Chloride Administration in Prenatal Stage on One-Trial Passive Avoidance Learning in Chicks. Biol Trace Elem Res. 2008;127(1):37-44. DOI: 10.1007/s12011-0088225-5

29. Liu Y, Chen D, Chen A, et al. Study on lanthanum deposit in liver of rats chronically exposed to lanthanum nitrate at low dose. Jou of Health Toxicol. 2003;17(4):203-205.

30. Huang P, Li J, Zhang S, Chen C, Han Y, Liu N, et al. Effects of lanthanum, cerium, and neodymium on the nuclei and mitochondria of hepatocytes: Accumulation and oxidative damage. Environ Toxicol Pharmacol. 2011; 31(1):25-32. DOI: 10.1016/j.etap.2010.09.001

31.Wu M, Gao J-L, Sun M-X, Zhang Y-Z, Liu Y,Dai J. Effects of La(III) and $\mathrm{Ca}(\mathrm{II})$ on Isolated Carassius auratus Liver Mitochondria: Heat Production and Mitochondrial Permeability Transition. Biol Trace Elem Res. 2015;163(1-2):217-223. doi: 10.1007/s12011-014-0178-2

32. Gagné F. Biochemical ecotoxicology: principles and methods. Book. 2014: p, 257.

33.Vasseur P, Cossu-Leguille C. Biomarkers and community indices as complementary tools for environmental safety. Environ Int. 2003;28(8):711-7. doi: 10.1016/S0160-4120(02)00116-2

34. Burgeot T,Gagné F. Contaminant exposure and ecotoxicological impacts in estuaries. Environmental Science and Pollution Research. Environ Sci Pollut Res. 2013;20(2):599-600. doi: 10.1007/s11356012-1324-z

35. Binelli A, Della Torre C, Magni S, Parolini M. Does zebra mussel (Dreissena polymorpha) represent the freshwater counterpart of Mytilus in ecotoxicological studies? A critical review. Environmental Pollution. 2015;196:386-403. doi: 10.1016/j.envpol.2014.10.023

36. Bradford MM. A rapid and sensitive method for the quantitation of microgram quantities of protein utilizing the principle of protein-dye binding. Anal Biochem. 1976;72:248-254.

37. Olive PL. DNA precipitation assay: a rapid and simple method for detecting DNA damage in mammalian cells. Environ Mol Mutagen. 1988;11(4):487-495.

38. Dudognon T, Lambert C, Quere C, Auffret M, Soudant P,Kraffe E. Mitochondrial activity, hemocyte parameters and lipid composition modulation by dietary conditioning in the Pacific oyster Crassostrea gigas. J Comp Physiol B. 2014; 184(3):303-317.doi: 10.1007/s00360013-0800-1

39. Scheuhammer AM,Cherian MG. Quantification of metallothioneins by a silver-saturation method. Toxicol Appl Pharmacol. 1986;82(3):417425 .

40. Gagné F, Marion M,Denizeau F. Metal homeostasis and metallothionein induction in rainbow trout hepatocytes exposed to cadmium. Fundam. Appl. Toxicol. 1990;14(2):429-437. doi: 10.1016/02720590(90)90221-5

41. Kille P, Hemmings A,Lunney EA. Memories of metallothionein. Biochim Biophys Acta. 1994;1205(2):151-161.

42. Weltje L, Heidenreich H, Zhu W, Hubert Th Wolterbeek, Siegfried Korhammer, Jeroen J M de Goeij, et al. Lanthanide concentrations in freshwater plants and molluscs, related to those in surface water, pour water and sediment. A case study in The Netherlands. Sci. Total Environ. 2002;286(1-3):191-214. doi: 10.1016/S00489697(01)00978-0

43. Rainbow PS. Trace metal concentrations in aquatic invertebrates: Why and so what? Environ. Pollut. 2002;120(3): 497-507. doi: 10.1016/ s0269-7491(02)00238-5

44. Hong J, Pan X, Zhao X, Yu X, Sang X, Sheng L, et al. Molecular mechanism of oxidative damage of lung in mice following exposure to lanthanum chloride. Environ. Toxicol. 2015;30(3):357-365. doi: $10.1002 /$ tox.21913

45. Zhao H, Cheng Z, Hu R, Chen J, Hong M, Zhou M, et al. Oxidative Injury in the Brain of mice Caused by Lanthanid. Biol. Trace Elem. Res. 2011;142(2):174-189. doi: 10.1007/s12011-010-8759-1 
46. Shi Y, Gou B-D, Shi Y-L, Zhang T-L,Wang K. Lanthanum chloride suppresses hydrogen peroxide-enhanced calcification in rat calcifying vascular cells. BioMetals. 2009;22(2):317-327. doi: 10.1007/s10534008-9168-1

47. Wakabayashi T, Ymamoto A, Kazaana A, Nakano Y, Nojiri Y, Kashiwazaki M. Antibacterial, Antifungal and Nematicidal Activities of Rare Earth Ions. Biol. Trace Elem. Res. 2016;174(2):464-470. doi: 10.1007/s12011-016-0727-y

48. Li T-S, Marbán E. Physiological levels of reactive oxygen species are required to maintain genomic stability in stem cells. Stem cells (Dayton, Ohio). 2010;28(7):1178-1185. doi: 10.1002/stem.438

49. Ling Q, Hong F. Antioxidative role of cerium against the toxicity of lead in the liver of silver crucian carp. Fish Physiol. Biochem. 2010;36(3):367-376. doi: 10.1007/s10695-008-9301-7

50. Liu J, Ma L, Yin S, Hong F. Effects of Ce3+ on Conformation and Activity of Superoxide Dismutase. Biol. Trace Elem. Res. 2008;125(2):170178. doi: $10.1007 / \mathrm{s} 12011-008-8165-0$

51. Dong S, Zhao Y, Liu H, Yang X, Wang K. Duality of effect of La3+ on mitochondrial permeability transition pore depending on the concentration. BioMetals. 2009;22(6):917-926. doi: 10.1007/s10534009-9244-1

52. Kim SG, Choi SH. Gadolinium Chloride Inhibition of Rat Hepatic Microsomal Epoxide Hydrolase and Glutathione S-Transferase Gene Expression Drug Metab Dispos. 1997;25(12):1416-1423.

53. Yadav SS, Kumar R, Khare P, Tripathi M. Oxidative Stress Biomarkers in the Freshwater Fish, Heteropneustes fossilis (Bloch) Exposed to Sodium Fluoride: Antioxidant Defense and Role of Ascorbic Acid Toxicol. Int. 2015;22(1):71-76. doi: 10.4103/0971-6580.172261

54. Wang Q, Xu J, Zhu Y, Chai B, Liang A, Wang W. Lanthanum(III) Impacts on Metallothionein MTT1 and MTT2 from Tetrahymena thermophila. Biol. Trace Elem. Res. 2011;143(3):1808-1818. doi: 10.1007/s12011011-9004-2

55. Kobayashi K, Shida R, Hasegawa T, et al. Induction of Hepatic Metallothionein by Trivalent Cerium: Role of Interleukin 6. Biological and Pharmaceutical Bulletin. 2005; 28(10): 1859-63. doi: 10.1248/ bpb.28.1859.

56. Amiard JC, Amiard-Triquet C, Barka S, Pellerin J, Rainbow PS Metallothioneins in aquatic invertebrates: Their role in metal detoxificationand their use as biomarkers. Aquat Toxicol. 2006;76(2):160-202. doi: 10.1016/j.aquatox.2005.08.015

57. Barka S, Pavillon JF, Amiard JC. Influence of different essential and non-essential metals on MTLP levels in the Copepod Tigriopus brevicornis. Comparative Biochemistry and Physiology - C Toxicology and Pharmacology. 2001; 128(4):479-493. doi: 10.1016/s15320456(00)00198-8

58. Siu PM, Donley DA, Bryner RW, Alway SE. Citrate synthase expression and enzyme activity after endurance training in cardiac and skeletal muscles. J. Appl. Physiol. 2003;94(2):555-560. doi:10.1152/ japplphysiol.00821.2002

59. Rooyackers OE, Adey DB, Ades PA, Nair KS. Effect of age on in vivo rates of mitochondrial protein synthesis in human skeletal muscle. Proceedings of the National Academy of Sciences of the United States of America. Proc Natl Acad Sci U S A. 1996; 93(26):15364-15369.

60. Hosseini A, Sharifi MA, Abdollahi M, Najafi R, Baeeri M, Rayegan S, et al. Cerium and Yttrium Oxide Nanoparticles Against Lead-Induced Oxidative Stress and Apoptosis in Rat Hippocampus. Biol Trace Ele Res. 2015;164(1):80-89. doi: 10.1007/s12011-014-0197-z

61. Ježek P, Hlavatá L. Mitochondria in homeostasis of reactive oxygen species in cell, tissues, and organism. The International Journal of Biochemistry \& Cell Biology. 2005;37(12):2478-2503. doi: 10.1016/j. biocel.2005.05.013

62. Feldstein AE, Werneburg NW, Canbay A, Guicciardi ME, Bronk SF, Rydzewski R, et al. Free fatty acids promote hepatic lipotoxicity by stimulating TNF- $\alpha$ expression via a lysosomal pathway. Hepatology. 2004;40(1):185-94. doi: 10.1002/hep.20283

63. Riri M, HM, Kamal O, Eljaddi T, Benjjar A, Hlaïbi M. New gadolinium(III) complexes with simple organic acids (Oxalic, Glycolic and Malic Acid). J Mater Environ Sci. 2011;2(3):303-308.

64. Gagne F, Auclair J, Peyrot C,Wilkinson KJ. The influence of zinc chloride and zinc oxide nanoparticles on air-time survival in freshwater mussels. Comp Biochem Physiol C Toxicol Pharmacol. 2015;173:3644.

65. Li B, Xie Y, Cheng Z, Cheng J, Hu R, Sang X, et al. Cerium Chloride Improves Protein and Carbohydrate Metabolism of Fifth-Instar Larvae of Bombyx mori Under Phoxim Toxicity. Biol Trace Elem. Res. 2012;150(1):214-220. doi: 10.1007/s12011-012-9465-ys 